\title{
A new record of Calassomys apicalis (Rodentia, Cricetidae) in the Espinhaço Mountain Range, Brazil
}

\section{Christian Nathan da Silva Oliveira ${ }^{1 *}$, Rone Fernando Carvalho ${ }^{1}$, Marco Aurélio da Cunha Moreira Pacheco ${ }^{1}$ \& Leonardo Guimarães Lessa ${ }^{1}$}

${ }^{1}$ Programa de Pós-Graduação em Biologia Animal, Universidade Federal dos Vales do Jequitinhonha e Mucuri, Campus JK, Diamantina, Minas Gerais, Brasil. E-mails: *C.nathan@live.com; ronefernando@gmail.com; macmpacheco@gmail.com; leoglessa@gmail.com.

Abstract. We present herein the record of the monotypic sigmodontine rodent Calassomys apicalis Pardiñas, Lessa, Salazar-Bravo and Câmara 2014 in the Brazilian Cerrado, based on two adult male specimens collected in a rocky outcrops area (campo rupestre) in southern portion of Espinhaço Mountain Range, in May and June 2016. This taxon was previously known only from the type locality at Parque Nacional das Sempre Vivas, Minas Gerais State, Brazil. The fecal analysis of the specimens collected in this study indicates a diversified diet with the consumption of arthropods and vegetative parts of plants in different proportions, being the first record about the feeding habits of this species.

Key words: Cerrado, campos rupestres, diet, endemism, Phyllotini.

Resumo. Um novo registro de Calassomys apicalis (Rodentia, Cricetidae) na Cadeia do Espinhaço, Brasil. Apresentamos aqui o registro do monotípico sigmodontideo Calassomys apicalis Pardiñas, Lessa, Salazar-Bravo e Câmara 2014 no Cerrado Brasileiro, com base em dois espécimes de machos adultos coletados em área de afloramentos rochosos (campo rupestre) na porção sul da Cadeia do Espinhaço, em maio e junho de 2016. Este táxon era anteriormente conhecido apenas da localidade tipo no Parque Nacional das Sempre Vivas, Minas Gerais, Brasil. A análise fecal dos espécimes coletados neste estudo indica uma dieta diversificada com o consumo de artrópodes e partes vegetativas de plantas em diferentes proporções, sendo este o primeiro registro sobre os hábitos alimentares desta espécie.

Palavras-chave: Cerrado, campos rupestres, dieta, endemismo, Phyllotini.

\section{INTRODUTION}

Calassomys is a recently described rodent genus and has the smallest geographic range of any within the tribe Phyllotini (PATTON et al., 2015). Calassomys apicalis Pardiñas, Lessa, Salazar-Bravo and Câmara 2014, is a monotypic medium sized rodent known only from the type local- ity, in Parque Nacional das Sempre Vivas, Minas Gerais State, Brazil. This taxon is rare in small mammal surveys and the available data on natural history of $C$. aplicalis mention that this species inhabits rock outcrops within campos rupestres (field rocks) in the Cerrado biome (PARDIÑAS et al., 2014; PATtON et al., 2015). Campos rupestres 
stricto sensu are a Neotropical, azonal vegetation complex endemic to Brazil (ALves et al., 2014). Its vegetation displays xerophytic adaptations and occurs on highly acidic, clayless and siltless soils with exposed rocks often covered by lichens and rupestrial plants at elevations between 900 and 2000 m (Alves et al., 2014; PARDiÑAs et al., 2014).

Calassomys apicalis is characterized by a moderately large and naked ear and a long bicolored tail with a totally white distal end. Its dentition is characterized by the persistence of vestigial mesolophs and mesostyles on booth upper $1^{\text {st }}$ and $2^{\text {nd }}$ molars, unique features within the Phyllotini. The karyotipe of $C$. apicalis shows a diploid number $(2 n)$ of 62 and fundamental number (FN) of 116 chromossomes (PARDIÑAs et al., 2014).
To date, the available data on natural history of $C$. apicalis mention that this is a terrestrial rodent that inhabits campos rupestres (PARDIÑAs et al., 2014), but, there is no information on diet, reproduction or population structure for this species. The goal of the present study is to report the first record of $C$. apicalis outside the type locality and provide information on their diet.

\section{MATERIAL AND MethodS}

We collected two adult males of $C$. apicalis in a campo rupestre area $\left(18^{\circ} 11^{\prime} \mathrm{S}\right.$; $43^{\circ} 34^{\prime}$ W; elevation $1322 \mathrm{~m}$ a. s. I.) in southern portion of Espinhaço Mountain Range, northern Minas Gerais State, during two field traps in May and June 2016 (Figure 1). The climate is type Cwb, ac-

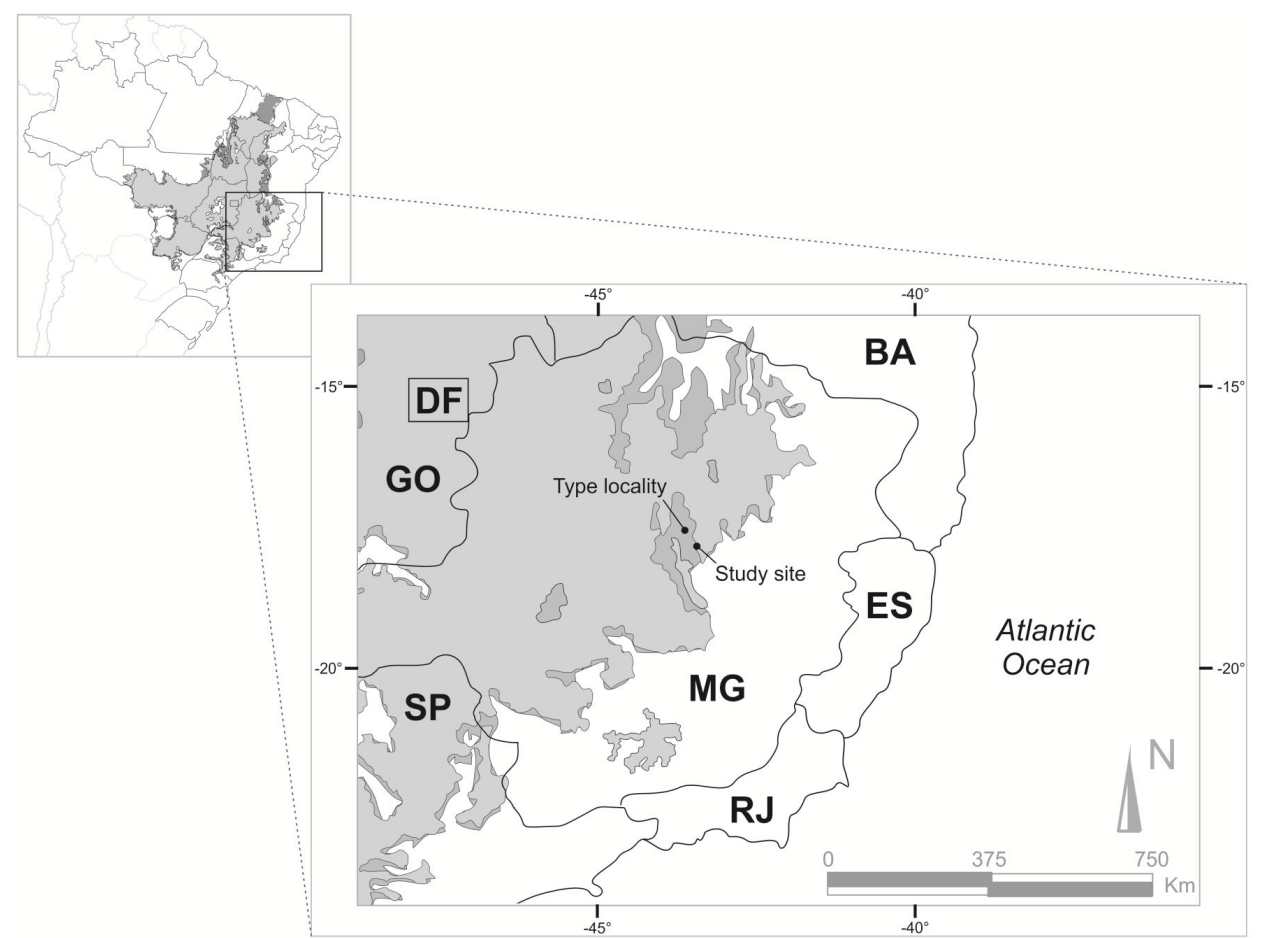

Figure 1. Map showing type locality of Calassomys apicalis at Parque Nacional das Sempre Vivas, Minas Gerais state, Brazil, and the location of our study site. 
cording to the Köppen classification, with mild, humid summers (October to April) and cool and dry winters (June to August). The average annual rainfall varies from 223 to $1550 \mathrm{~mm}$ and the average annual temperature ranges from $17{ }^{\circ} \mathrm{C}$ to $19{ }^{\circ} \mathrm{C}$ (NEVEs et al., 2005). All specimens were collected in an area of rocky outcrops close to a watercourse surrounded by bush/shrub vegetation, as well as open grasslands areas.

The specimens were trapped in Tomahawk traps $(300 \times 160 \times 160 \mathrm{~mm})$ set on the ground and baited with a mixture of banana, sardine oil, corn meal and oat grains. Two voucher specimens (both adult males) were preserved as study skin, skull, post-cranial skeleton, and tissue samples (liver fixed in $96 \%$ ethanol), and have been deposited in the Scientific Collection of the Departamento de Ciências Biológicas/Uni- versidade Federal dos Vales do Jequitinhonha e Mucuri, Diamantina, Minas Gerais, Brazil, under the catalog numbers MDIA114 and MDIA116. Instituto Chico Mendes de Conservação da Biodiversidade (ICMBio) issued the collecting permit (license no. 52836-1).

We examined external and dental morphology of the two voucher specimens of $C$. apicalis (Figure 2) and confirmed the taxonomic identification comparing with other taxonomic specimens from the type locality housed in the Scientific Collection of the Museu de Ciências Naturais da Pontifícia Universidade Católica de Minas Gerais (catalog numbers MCN-M2176; MCN-M2188), Minas Gerais, Brazil. Morphologic characteristics considered for species diagnosis follows PARDIÑAs et al. (2014).

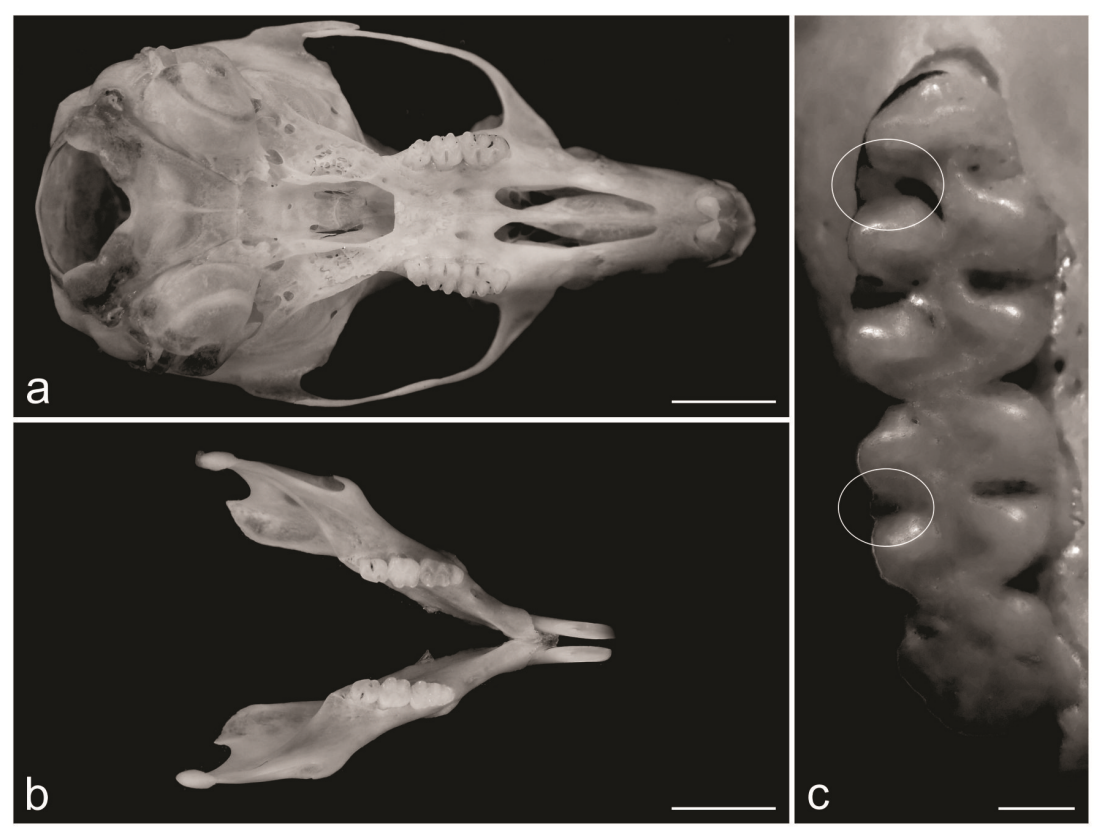

Figure 2. Ventral view of the skull and jaw of Calassomys apicalis highlighting the persistence of vestigial mesolophs and mesostyles on booth upper $1^{\text {st }}$ and $2^{\text {nd }}$ molars (white circles). Photo by Pacheco MAC. Scale bar $=5 \mathrm{~mm}(\mathrm{~A}$ and B); $0.5 \mathrm{~mm}$ (C). 
We also collected feces directly from each specimen during manipulation or inside the trap. The samples were stored in paper envelopes and preserved at $-10{ }^{\circ} \mathrm{C}$ to avoid fungi infestation. One fecal sample was considered as being all feces produced by a single captured animal in a night. In laboratory, feces were examined under a stereoscopic microscope and food items were identified to the lowest taxonomic level.

The following small mammal's species were also captured in the same trap-lines that C. apicalis, the cricetids Oligoryzomys nigripes (OLFERS, 1818) and Cerradomys subflavus (WAGNER, 1842); the echimyid Thrichomys apereoides (LUND, 1839) and the didelphid marsupial Monodelphis domestica (WAGNER, 1842).

\section{RESULTS AND DISCUSSION}

According to the available data, C. apicalis has a restricted range distribution, occurring in campos rupestres montane savannas at Espinhaço Mountain Range (PATTON et al., 2015). The Espinhaço Range has been acknowledged as a center of endemism for plants (GIULLIETTI et al. 1997), anurans, lizards and birds (RODRIGUES, 1987; Pugliese et al., 2004; ETEROVICK et al., 2005; NASCIMENTO et al., 2005; RODRIGUES et al., 2005). However, as for the mammals, most species inhabiting campos rupestres are ordinarily found in other physiognomies in the Cerrado biome (LESSA et al., 2008; SILVA et al., 2014). Thus far, due to the insufficiency of faunistic inventories, future researches are necessary to clarify if C. apicalis are restricted to this kind of habitat, at rock outcrops of the Espinhaço Range or if such species are restricted to mountains or massifs with campos rupestres, but not necessarily endemic to this vegetation complex (see SILva et al., 2014). Up to now, just one other Philotini rodent, Oligoryzomys rupestris Weskler \& Bonvicino, 2005, are known exclusively from campos rupestres, with scattered populations in the Brazilian States of Goias, Minas Gerais, and Bahia at elevations above $1000 \mathrm{~m}$ a. s. I. (WEKSLER \& BONVICINO, 2005). The paucity of geographic information on C. apicalis, also reflects how little is known about the biology of this species, and until now, information about its feeding habits are inexistent. The fecal analysis of the specimens collected in this study indicates the consumption of arthropods (mainly Isoptera and Hymenoptera), vegetative parts of plants (leaves and stems) and also flowers. A diversified diet with the consumption of arthropods and vegetative parts of plants in different proportions was also observed in other rodent species in campos rupestres such as Cerradomys subflavus and Thrichomys apereoides (LESSA \& COSTA, 2009; PAULA et al. 2016 in press).

The increase in recent years of new small mammal's records in campos rupestres areas at the Espinhaço Mountain Range is noteworthy, and has provided important data on its distribution, taxonomy and ecology (see PEREIRA \& GEISE, 2009; PARDIÑAs et al., 2014; Loss et al., 2015; BRAGA et al., 2016). Nevertheless, the current level of knowledge on the composition and distribution of Phyllotini rodents in habiting rock outcrops in campos rupestres across this wide re- 
gion is still scarce.

\section{ACKNOWLEDGEMENTS}

We are grateful to the Instituto Chico Mendes de Conservação da Biodiversidade (ICM$\mathrm{BIO}$, Chico Mendes Institute for Biodiversity Conservation) for issuing the license to capture the animals (license no. 52836-1).

\section{REFERENCES}

Alves, R.J.V.; Silva, N.G.; OliVEIRA, J.Á. \& MedeIROS, D. 2014. Circumscribing campo rupestre - megadiverse Brazilian rock montane savanna. Brazilian Journal of Biology 74(2): 355-362.

Braga, C.A.C.; Drumond, L.O. \& PIRES, M.R.S. 2016. Small mammals (Rodent and Didelphimorphia) from Serra do Ouro Branco: southern portion of Espinhaço Mountains Range, Minas Gerais, Brazil. Oecologia Australis 20(1): 69-80.

Eterovick, P.C.; CARnaval, A.C.O.; Borges-NojoSA, D.M.; Silvano, D.L.; Segalla, M.V. \& SAZIMA, I. 2005. Amphibian Declines in Brazil: An Overview. Biotropica 37(2): 166-179.

LESSA, L.G.; COSTA, B.M.A.; RosSONI, D.M.; TAVARES, V.C.; DIAS, L.G.; JUNIOR, E.A.M. \& SilvA, J.A. 2008. Mamíferos da Cadeia do Espinhaço: riqueza, ameaças e estratégias para conservação. Megadiversidade 4(12): 218-232.

LESSA, L.G. \& COSTA, F.N. 2009. Food habits and seed dispersal by Thrichomys apereoides
(Rodentia: Echimyidae) in a Brazilian Cerrado reserve. Mastozoología Neotropical 16(2): 459-464.

Loss, A.C.; PACHECO, M.A.C.; LeITE, Y.R.L.; CALDARA-JUNIOR, V. \& LESSA, L.G. 2015. Range extension and first record of Euryzygomatomys spinosus (Rodentia, Echimyidae) in the Brazilian Cerrado. Checklist 11(5): 1742.

NASCimento, L.B.; WACHLEVSCKI, M. \& Leite, F. 2005. Anuros, pp 210-229. In: Silva, A.C.; Pedreira, L.C.V.S.F. \& Abreu, P. (ed.). Serra do Espinhaço Meridional: paisagens e ambientes. Belo Horizonte, Ed. O Lutador. 271p.

Neves, S.C.N.; Abreu, P.A.A. \& FragA, L.M.S. 2005. Fisiografia, pp 47-58. In: Silva, A.C.; Pedreira, L.C.V.S.F. \& Abreu, P.(ed.). Serra do Espinhaço Meridional: paisagens e ambientes. Belo Horizonte, Ed. O Lutador. $271 p$.

Paula, C.S.; Lessa, L.G. \& PessoA, R.S. (in press). Food habits and seed dispersal by rodents (Cricetidae and Echimyidae) in a riparian forest in southeastern Brazil. Oecologia Australis.

PARdiñAS, U.F.J.; LeSSA, G.; TeTA, P.; SAlazar-BraVo, J. \& CAMARA, E.M.V.C. 2014. A new genus of Sigmodontine rodent from eastern Brazil and the origin of the tribe Phyllotini. Journal of Mammalogy 95(2): 201-215.

PATTON, J.L.; PARDiñas, U.F.J. \& D'ÉliA, G. 2015. 
Mammals of South America. Vol. 2: Rodents. Chicago, The University of Chicago Press. $1336 p$.

PereirA, L.G. \& GeISE, L. 2009. Non-flying mammals of Chapada Diamantina, Bahia, Brazil. Biota Neotropica 9(3): 188-196.

Pugliese, A.; Pombal-JR, J.P. \& Sazima, I. 2004. A new species of Scinax (Anura: Hylidae) from rocky montane fields of the Serra do Cipó, Southeastern Brazil. Zootaxa 688: 1-15.

RODRIGUES, M.T. 1987. Distribution of lizards of the genus Tropidurus in Brazil (Sauria, Iguanidae), pp 305-305. In: Vanzolini, P.E. \& Heyer, W.R.(ed). Proceedings of a workshop on Neotropical distribution pattern held. Rio de Janeiro, Academia Brasileira de Ciências 1987. 488p.

Rodrigues, M.; CARrara, L.A.; FARIA, L.P. \& GoMES, H.P. 2005. The birds of "Parque Nacional da Serra do Cipó": the Rio Cipó valley, Minas Gerais, Brazil. Revista Brasileira de Zoologia 22(2): 326-338.

Weksler, M. \& Bonvicino, C.R. 2005. Taxonomy of pigmy rice rats genus Oligoryzomys Bangs 1900 (Rodentia, Sigmodontinae) of the Brazilian Cerrado, with the description of two new species. Arquivos do Museu Nacional 63(1): 113-130.
Recebido: 08/03/2017

Revisado: 25/04/2017

Aceito: 03/05/2017 